Kinestetik : Jurnal Ilmiah Pendidikan Jasmani 5 (4) (2021)

\title{
LEARNING TECHNIQUES SMASH VOLLEYBALL GAME LARGE SCALE TRIALS
}

\author{
Destriana $^{1 *}$, Destriani ${ }^{2}$, Muslimin $^{3}$, \\ ${ }^{1,2}$ Health and Recreation Physical Education Study Program, Faculty of Teacher Training and \\ Education, Universitas Sriwijaya, Palembang, Indonesia \\ ${ }^{3}$ Sports Education, Faculty of Teacher Training and Education, Universitas Bina Darma, \\ Palembang, Indoenesia
}

\section{Article Info \\ Article History : \\ Received : August 2021 \\ Revised : September 2021 \\ Accepted : September 2021 \\ Available online : December 2021}

\section{Keywords:}

Learning, smash, volleyball

\begin{abstract}
The purpose of this study was to develop the volleyball game drill smash learning technique for the students of Universitas Sriwijaya Phisical education. This study uses a mixed approach, Research and Development research methods. This study uses observation instruments and questionnaires as a means of collecting data. The research steps consisted of needs analysis, product draft planning, expert validation, small-scale trials, product revisions, large-scale trials and revisions. This study used 3 validation experts, namely Physical Education experts, volleyball game experts and linguists, with the small-scale test subjects of 24 UNSRI Physical Education students, and 105 students for large-scale trials. The research resulted in 12 drill smash learning techniques that were declared valid from 3 experts, namely with an average of $82.3 \%$, smallscale trials obtained an average result of $88.9 \%$ of students who could use this development technique and get $95.54 \%$ results and not There are significant prohibitions in large-scale trials so that this learning development technique is suitable for use in volleyball smash learning. The development of 12 volleyball drill smash learning techniques that can be used for Physical Education students, especially the volleyball game smash material and can be used by teachers as an added reference in teaching volleyball games are the findings of this study.
\end{abstract}

\begin{tabular}{llr}
\hline Corresponding address & : Sarjana Green Indralaya Block C 16 & ISSN 2685-6514 (Online) \\
*Corresponding email & $:$ destriana @fkip.unsri.ac.id & ISSN 2477-331X (Print)
\end{tabular}




\section{INTRODUCTION}

Volleyball is characterized as a ball game that requires biomechanics that demands the musculoskeletal system as well as coordination, speed, agility, and neuromuscular strength.

"Volleyball is characterized as a ball game that requires biomechanical demands upon the musculoskeletal system as well as a great deal of neuromuscular coordination, speed, agility, and power, passing, setting, spiking, blocking and serving the ball are fundamental movements in a volleyball game, which requires implementation of various vertical or horizontal jumps, and speed actions. It has been suggested that volleyball players competing in better performing teams, have higher vertical jump values" (Ikeda, Sasaki, \& Hamano, 2018), and volleyball shows a relatively small number of injuries compared to other team sports such as ice hockey, handball, or football (Miltner \& Wurm, 2017).

(Rahman, Sahputra, \& Wakidi, 2014) stated that the smash is the movement of the ball being hit downwards by involving great force by jumping upwards, and towards the other team's field. (Medeiros, Mesquita, Marcelino, \& Palao, 2014) the smash technique is said to be effective not based on the severity of the smash result but as the result of the smash can make it difficult for the opposing team. (Iskandar \& Satrio, 2016) stated that the thing to note is that the smash is not the severity of the smash but the resulting ball can be difficult for the opposing team. Effective smash movements are carried out in 3 ways, namely doing tricks, slow smashes and hard smashes (Hermansyah \& Permadi, 2018), (Aulia \& Hermanzoni, 2018) and (Indrayana, 2018) for the smash are at positions 2,3, and 4 .
In the Physical Education Study Program, Health and Recreation, Sriwijaya University, one of the compulsory subjects is the basic skills of playing volleyball.

Problems were found when the volleyball game learning process took place, especially during the smash material. It can be seen that students have difficulty in performing the smash technique, one of the factors is the level of difficulty in the smash material itself, besides that, because of the difficulty of this material, the motivation of students to do smash decreases and has a bad impact during the implementation of the learning assessment process, further observations were carried out in several study programs. in the city of Palembang and found problems that are not much different. This problem is used as the basis for conducting this research.

Teachers must use effective and efficient techniques or models for students so that the focus in class is only on teaching and learning activities. Teaching materials for teachers are the key to creating creativity for teachers and combined with learning media so that learning activities will be better.

(Risma, Dlis, \& Samsudin, 2020) found in research that smash techniques can be improved by using a game model approach, in addition (Destriani, Destriana, Switri, \& Yusfi, 2019) where to develop a learning model about the volleyball game which includes facilities, infrastructure, and rules for playing volleyball. Looking at the previous research presented above regarding the development of smashing learning, there are models in the form of circuits and other developments using a game model approach, as well as the development of facilities, infrastructure and game rules so that it is felt that there are still parts that do not exist to produce developments that are different from 
previous research. This research is a continuation of (Destriana et al., 2021) which only examines the stage of conducting a validation test of the drill smash learning technique expert so that this research must be continued at the next stage.

This research was carried out with the hope that it could be a solution to these problems, this research was held aimed at developing appropriate smash learning techniques in teaching volleyball learning, especially on smash material, it is hoped that with the development of this drill smash learning technique, smash learning outcomes will increase, so that students will be interested and happy to do samsh volleyball game learning, besides that the development of volleyball game smash learning techniques is expected to be able to

\section{METHODS}

The development of this smash learning technique is a research that uses a mixed methods research approach that combines qualitative and quantitative methods, the research method used is the research and development method from Borg and Gall. According to (Munawaroh, 2016) the production of new products or improving existing products that can be accounted for is called research and development. The research stages were adapted from the book "Educational Research" (Gall, Gall, \& Borg, 2006) namely research and information collection in the form of theoretical studies, subject observation, report preparation, planning, initial product development, large-scale field testing, revision of the main product, conducting product revisions, effectiveness testing, and dissemination.

\section{Participants}

The validation of the experts involved in this study were health education learning experts, volleyball game experts and linguists, this largescale trial involved 105 students from 3 universities, namely 53 Sriwijaya University students, 32 PGRI University students and 20 Binadarma Palembang students.

\section{Sampling Procedures}

This study used a purposive sampling technique where the sample is taken with a specific purpose. The sample consisted of 3 universities in the city of Palembang, namely Sriwijaya University, PGRI Palembang and Bina Darma. Samples were taken on students who had received volleyball courses and took one class at each university. This research has permission to conduct research at related universities with clear research objectives. This study uses research subjects based on research objectives, namely physical education students who voluntarily become research subjects, with a limited number due to the covid 19 pandemic, so they must comply with health protocols.

\section{Materials and Apparatus}

To determine the feasibility category of the smash learning technique for students, a questionnaire is given to be assessed by experts (expert judgment) and teachers in the field test. The results of the appropriate or inappropriate assessment by the expert are then converted into scores and the percentage of the results is calculated. After that, it can be concluded that the results are feasible and not feasible from the learning technique or product. 


\section{Design or Data Analysis}

The results of the next data calculation are made in the form of a percentage multiplied by $100 \%$. After obtaining the percentage with the formula, then the feasibility of the volleyball skill-based test instrument in this development research is classified into four eligibility categories using the following scale. Category Percentage Eligibility.

\section{RESULTS}

The initial stage of the research is a needs analysis. The results of expert validation on the development of volleyball game smash learning techniques obtained an average of $82.3 \%$ and declared valid (valid) to be tested, next is a small-scale trial obtained an average result of $88.9 \%$ of students can implement ball smash learning techniques volleyball consisting of 24 students of the Unsri Penjaskesrek Study Program.

This research was conducted at 3 universities in Palembang. The number of subjects was 53 Unsri Physical Education and Health students, 20 Sports Education students at Bina Darma University Palembang, and 32 Sports Education students at PGRI Palembang University. The subjects used were different from the previous subjects in small-scale trials. After testing in large groups, data analysis was carried out based on the results of large-scale trials with the following results:

Table 1. Results of Large-Scale Trial $(n=105)$

\begin{tabular}{clc}
\hline No & \multicolumn{1}{c}{$\begin{array}{c}\text { Drill Smash . Learning } \\
\text { Techniques }\end{array}$} & $\begin{array}{c}\text { Inform } \\
\text { ation } \\
\mathbf{y}\end{array}$ \\
\hline 1. & $\begin{array}{l}\text { Drill smash with step prefix and } \\
\text { smash position without the ball }\end{array}$ & Valid \\
\hline \multirow{2}{*}{$\begin{array}{l}\text { Drill smash without starting hit } \\
\text { the ball towards the floor } \\
\text { without jumping }\end{array}$} & Valid \\
\hline
\end{tabular}

\begin{tabular}{cll}
\hline 3. & $\begin{array}{l}\text { Drill smash without starting } \\
\text { hitting the ball against the wall } \\
\text { without jumping }\end{array}$ & Valid \\
\hline 4. & $\begin{array}{l}\text { Drill smash by catching the ball } \\
\text { in the air }\end{array}$ & Valid \\
\hline 5. & $\begin{array}{l}\text { Drill smash against the wall } \\
\text { with prefix and jump }\end{array}$ & Valid \\
\hline & $\begin{array}{l}\text { Drill smash in pairs without } \\
\text { starting } 3 \text { meters distance } \\
\text { without net }\end{array}$ & Valid \\
\hline 7. & $\begin{array}{l}\text { Drill smash in pairs without } \\
\text { starting } 5 \text { meters distance } \\
\text { without net }\end{array}$ & Valid \\
\hline 8. & $\begin{array}{l}\text { Drill smash in pairs with a } \\
\text { distance of } 3 \text { meters over the net }\end{array}$ & Valid \\
\hline 9. & $\begin{array}{l}\text { Drill smash in pairs with a } \\
\text { distance of 5 meters over the net }\end{array}$ & Valid \\
\hline 10. & Drill smash 3 targets & Valid \\
\hline 11 & $\begin{array}{l}\text { Drill smash 5 targets with the } \\
\text { help of friends }\end{array}$ & Valid \\
\hline 12 & Drill smash with 5 passes & Valid \\
\hline & \multicolumn{1}{c}{ Rata-rata } \\
\hline
\end{tabular}

The results of large-scale trials conducted on 12 volleyball smash learning techniques are already feasible to use, the results of the trials can be seen in table 2 as follows:

Table 2.

\begin{tabular}{ccccc}
\hline No & Indicator & Score & Percentage & Information \\
\hline 1 & Convenience & 12 & $100 \%$ & Valid \\
\hline 2 & Clarity & 11 & $91,67 \%$ & Valid \\
\hline 3 & Interest & 10 & $83 \%$ & Valid \\
\hline 4 & Keamanan & 12 & $100 \%$ & Valid \\
\hline 5 & Equipment & 12 & $100 \%$ & Valid \\
\hline & Average & & $94,93 \%$ & Valid \\
\hline
\end{tabular}

Table 2 above shows that the results of a large-scale trial in the Penjaskesrek study program, FKIP Sriwijaya University with a total of 53 students as subjects, obtained an average result of $94.93 \%$, this indicates that this development is feasible to use.

Table 3. Results of large-scale trials At Bina Darma University with $n=20$

\begin{tabular}{ccccc}
\hline No & Indicator & Score & Percentage & Information \\
\hline 1 & Convenience & 12 & $91,67 \%$ & Valid \\
\hline 2 & Clarity & 11 & $91,67 \%$ & Valid \\
\hline 3 & Interest & 10 & $91,67 \%$ & Valid \\
\hline
\end{tabular}




\begin{tabular}{ccccc}
\hline 4 & Keamanan & 12 & $100 \%$ & Valid \\
\hline 5 & Equipment & 12 & $100 \%$ & Valid \\
\hline \multicolumn{2}{c}{ Average } & & $95.01 \%$ & Valid \\
\hline
\end{tabular}

Table 4. Results of large-scale trials At the University of PGRI Palembang with $\mathrm{n}=32$

\begin{tabular}{|c|c|c|c|c|}
\hline No & Indicator & Score & Percentage & Information \\
\hline 1 & Convenience & 12 & 91,67 & Valid \\
\hline 2 & Clarity & 11 & 91,67 & Valid \\
\hline 3 & Interest & 10 & 100 & Valid \\
\hline 4 & Keamanan & 12 & $100 \%$ & Valid \\
\hline \multirow[t]{2}{*}{5} & Equipment & 12 & 100 & Valid \\
\hline & Average & & $96,67 \%$ & Valid \\
\hline
\end{tabular}

Table 4 above can be seen that the results of a large-scale trial in the Sports Education Study Program of PGRI Palembang with a number of subjects as many as 32 students obtained an average result of $96.67 \%$, this indicates that this development is feasible to use.

Table 5. Recapitulation of large-scale trial results with $n=105$

\begin{tabular}{ccccc}
\hline No & Indicator & Score & Percentage & Information \\
\hline 1 & Convenience & 12 & $94,47 \%$ & Valid \\
2 & Clarity & 11 & $91,67 \%$ & Valid \\
3 & Interest & 10 & $91,56 \%$ & Valid \\
4 & Keamanan & 12 & $100 \%$ & Valid \\
5 & Equipment & 12 & $100 \%$ & Valid \\
& Average & & $95,54 \%$ & Valid \\
\hline
\end{tabular}

Based on table 5 the results of large-scale trials conducted on 105 subjects resulted in a percentage of $95.54 \%$ so that the development of this smash learning technique is feasible to use. Suggestions and inputs based on questionnaires, in general, in the largescale trial phase, there were no significant obstacles during the trial.

\section{DISCUSSION}

The development of smash learning techniques using research and development methods with steps in Borg and Gall, this study produced a product in the form of 12 smash learning techniques that were feasible to use based on the results of research on largescale trials involving 105 students as test subjects. In producing the product, the researcher firstly identifies the needs (using survey which is qualitative in nature), develops a product, and then tests the effectiveness of the product (using an experiment) (Haryati, 2012).

This research begins with a needs analysis by observing, the results of the observation show that in the process of learning volleyball games, especially smash, it is difficult for students to smash, students seem to have difficulty doing the smash technique, so that students' desire to smash is reduced. (Reeser, Fleisig, Bolt, \& Ruan, 2010) in essence that the smash or spike movement has 4 stages, namely the initial phase, the hand swing phase, the acceleration phase, and the advanced movement phase.

The second stage in this research is product design starting from designing the goals to be achieved in the learning process, and formulating the goals to be achieved besides the design/design phase helps to focus and improve the researchers' efforts and create designs which can then build teaching content interesting and learning experience (Hess \& Greer, 2016) The objectives in this case lead to the development of courage, independence, and motoric development of children in the field, including; planning the preparation of smash learning technique materials, planning effective language use, planning procedures for implementing smash techniques, planning experts in their fields, and planning the learning process or daily activity plan so as to examine the instructional objectives, these instructional objectives are obtained based on the Semester Learning 
Plan to match the learning provided by the teacher at the university.

This study presents 3 expert validations in the assessment, namely; physical education expert, volleyball expert and linguist. The results of this research on design resistance showed that the developed learning was declared valid or feasible to use based on the results of expert validation with an average of $82.3 \%$ obtained and was declared valid to be tested on a small scale. The next stage is the scale trial stage. The small-scale trial involved 24 students of the Unsri physical education Study Program with the results of the study getting an average percentage of $88.9 \%$ suitable for use, after a smallscale trial, revisions were made based on input from experts.

Large-scale trials are the next step in this research after the product has been revised. The large-scale trial involved 105 students consisting of 53 Penjaskesrek students from Sriwijaya University, 20 sports education students at Bina Darma University and 30 sports education students from PGRI Palembang University. the development of volleyball smash learning techniques was declared feasible to be used in learning, research that also resulted in the development of volleyball smashes was (Pranopik, 2017) which resulted in the development of variations in volleyball smash drills that could improve the volleyball game smash, in addition (Nurfalah, Hanif, \& Satyakarnawijaya, 2019) developed an exercise model that can improve volleyball smash results for beginners, furthermore (Srianto, 2018) also resulted in the development of a smash practice model that was declared valid or suitable to be used to improve smash results, (Rahadian, 2019) also developed a model learner $\mathrm{n}$ in high school which is used to improve smash learning outcomes in volleyball games, (Kasih, 2018) create circuit learning model based training to improve technical capabilities smash volleyball, (Reeser, Fleisig, Bolt, \& Ruan, 2015) because shoulder kinetics were greatest during spiking, the volleyball player with symptoms of shoulder overuse may wish to reduce the number of repetitions performed during practice, from some of the results of this study it can be stated that the development of volleyball smash learning techniques for UNSRI physical education students is feasible or valid to be used in volleyball game smash learning. This study concludes that developments such as previous research are good such as research (Nurfalah et al., 2019; Rahadian, 2019; Srianto, 2018) could improve volleyball smash learning.

\section{CONCLUSION}

The conclusion of this research is that the development of drill smash learning techniques for volleyball games is declared valid to be used in learning, with the results of the development in the form of 12 drill smash learning techniques that can be used in smash learning. This development product is expected to be used both for teachers and lecturers as an additional reference when doing learning so as to improve the quality of learning the volleyball game smash.

\section{REFERENCES}

Aulia, Y., \& Hermanzoni. (2018). Pengaruh Bentuk Latihan Smash Terhadap Kemampuan Smash Pada Atlet Bolavoli M3c Pesisir Selatan. Jpo (Jurnal Performa Olahraga), Jurusan Kepelatihan Olahraga, Fakultas Ilmu Keolahragaan Universitas Negeri Padang. 
Destriana, Destriani, \& Yusfi, H. (2021). Development of Learning Technique Smash Volleyball Games. Https://Doi.Org/10.2991/Assehr.K.2 01230.145

Destriani, D., Destriana, D., Switri, E., \& Yusfi, H. (2019). The Development Of Volleyball Games Learning For Students. Jurnal Sportif: Jurnal Penelitian Pembelajaran. Https://Doi.Org/10.29407/Js_Unpgri .V5i1.12605

Gall, M. D., Gall, J. P., \& Borg, W. R. (2006). Educational Research: An Introduction, 8th Edition. Educational An Introduction.

Haryati, S. (2012). Research And Development (R\&D) Sebagai Salah Satu Model Penelitian Dalam Bidang Pendidikan. Research And Development $(R \& D)$ Sebagai Salah Satu Model Penelitian Dalam Bidang Pendidikan.

Hermansyah, \& Permadi, A. G. (2018). Peningkatan Ketepatan Smash Bola Voli Dengan Metode Target Games Pada Siswa Kelas Xi Sma Darul Hikmah Tahunpelajaran 2017/2018. Jisip, Jurnal Ilmu Sosial Dan Pendidikan.

Hess, A. K. N., \& Greer, K. (2016). Designing For Engagement: Using The Addie Model To Integrate High-Impact Practices Into An Online Information Literacy Course. Communications In Information Literacy.

Https://Doi.Org/10.15760/Comminf olit.2016.10.2.27

Ikeda, Y., Sasaki, Y., \& Hamano, R. (2018). Factors Influencing Spike Jump Height In Female College Volleyball Players. Journal Of Strength And Conditioning Research.

Https://Doi.Org/10.1519/Jsc.000000 0000002191

Indrayana, B. (2018). Perbedaan
Pengaruh Latihan Knee Tuck Jump Dengan Latihan Double Leg Bound Terhadap Peningkatan Power Otot Tungkai Dan Kemampuan Smash Pada Ekstrakurikuler Bola Voli Putra Smkn 1 Kota Jambi. Jorpres (Jurnal Olahraga Prestasi). Https://Doi.Org/10.21831/Jorpres.V $14 \mathrm{i} 1.19977$

Iskandar, \& Satrio. (2016). Meningkatkan Keterampilan Smash Bola Voli Melalui Metode Tugas Siswa Kelas Viii Smp Negeri 1 Ketapan. Edukasi, Jurnal Pendidikan.

Kasih, I. (2018). Development Of Learning Model Smash Volleyball Based Circuit. International Journal Of Science And Research (Ijsr). Https://Doi.Org/10.31227/Osf.Io/Mz pga

Medeiros, A. I. A., Mesquita, I. M., Marcelino, R. O., \& Palao, J. M. (2014). Effects Of Technique, Age And Player's Role On Serve And Attack Efficacy In High Level Beach Volleyball Players. International Journal Of Performance Analysis In Sport. Https://Doi.Org/10.1080/24748668. 2014.11868751

Miltner, O., \& Wurm, M. (2017). Volleyball. In Foot And Ankle Sports Orthopaedics. Https://Doi.Org/10.1007/978-3-31915735-1_70

Munawaroh, I. (2016). Urgensi Penelitian Dan Pengembangan. Universitas Negeri Yogyakarta.

Nurfalah, S., Hanif, A. S., \& Satyakarnawijaya, Y. (2019). Model Latihan Smash Dalam Permainan Bola Voli Untuk Pemula. Jurnal Pendidikan Olahraga. Https://Doi.Org/10.31571/Jpo.V8i1. 1216

Pranopik, M. R. (2017). Pengembangan Variasi Latihan Smash Bola Voli. 
Jurnal

Prestasi.

Https://Doi.Org/10.24114/Jp.V1i1.6 495

Rahadian, R. (2019). Model Pembelajaran Smash Bolavoli Pada Siswa Sekolah Menengah Kejuruan. Biormatika : Jurnal Ilmiah Fakultas Keguruan Dan Ilmu Pendidikan. Https://Doi.Org/10.35569/Biormatik a.V5i01.412

Rahman, A., Sahputra, R., \& Wakidi. (2014). Peningkatan Ketepatan Dan Kecepatan Smash Bola Voli Dengan Penerapan Media Audio Visual Pada Kelas Viii Smp Negeri 1 Pinoh Utara. Jurnal Pendidikan Jasmani Kesehatan Dan Rekreasi (Penjaskesrek).

Reeser, J. C., Fleisig, G. S., Bolt, B., \& Ruan, M. (2010). Upper Limb Biomechanics During The Volleyball Serve And Spike. Sports Health.

Https://Doi.Org/10.1177/194173811 0374624

Reeser, J. C., Fleisig, G. S., Bolt, B., \& Ruan, M. (2015). The Volleyball Serve And Spike. Sports Health.

Risma, S. A., Dlis, F., \& Samsudin, S. (2020). Variation Of Volleyball Basic Technique Through Games Approach. Active: Journal of Physical Education, Sport, Health And Recreation. Https://Doi.Org/10.15294/Active.V9 i2.39056

Srianto, W. (2018). Pengembangan Model Latihan Teknik Smash Dalam Olahraga Bola Voli. Trihayu: Jurnal Pendidikan Ke-Sd-An.

aulia, Y., \& Hermanzoni. (2018). Pengaruh Bentuk Latihan Smash Terhadap Kemampuan Smash Pada Atlet Bolavoli M3c Pesisir Selatan. Jpo (Jurnal Performa Olahraga), Jurusan Kepelatihan Olahraga, Fakultas Ilmu Keolahragaan Universitas Negeri Padang.
Destriana, Destriani, \& Yusfi, H. (2021). Development Of Learning Technique Smash Volleyball Games. Https://Doi.Org/10.2991/Assehr.K.2 01230.145

Destriani, D., Destriana, D., Switri, E., \& Yusfi, H. (2019). The Development Of Volleyball Games Learning For Students. Jurnal Sportif: Jurnal Penelitian Pembelajaran. Https://Doi.Org/10.29407/Js_Unpgri .V5i1.12605

Gall, M. D., Gall, J. P., \& Borg, W. R. (2006). Educational Research: An Introduction, 8th Edition. Educational An Introduction.

Haryati, S. (2012). Research And Development (R\&D) Sebagai Salah Satu Model Penelitian Dalam Bidang Pendidikan. Research And Development $(R \& D)$ Sebagai Salah Satu Model Penelitian Dalam Bidang Pendidikan.

Hermansyah, \& Permadi, A. G. (2018). Peningkatan Ketepatan Smash Bola Voli Dengan Metode Target Games Pada Siswa Kelas Xi Sma Darul Hikmah Tahunpelajaran 2017/2018. Jisip, Jurnal Ilmu Sosial Dan Pendidikan.

Hess, A. K. N., \& Greer, K. (2016). Designing For Engagement: Using The Addie Model To Integrate High-Impact Practices Into An Online Information Literacy Course. Communications In Information Literacy. Https://Doi.Org/10.15760/Comminf olit.2016.10.2.27

Ikeda, Y., Sasaki, Y., \& Hamano, R. (2018). Factors Influencing Spike Jump Height In Female College Volleyball Players. Journal Of Strength And Conditioning Research.

Https://Doi.Org/10.1519/Jsc.000000 0000002191

Indrayana, B. (2018). Perbedaan 
Pengaruh Latihan Knee Tuck Jump Dengan Latihan Double Leg Bound Terhadap Peningkatan Power Otot Tungkai Dan Kemampuan Smash Pada Ekstrakurikuler Bola Voli Putra Smkn 1 Kota Jambi. Jorpres (Jurnal Olahraga Prestasi). Https://Doi.Org/10.21831/Jorpres. V $14 \mathrm{i} 1.19977$

Iskandar, \& Satrio. (2016). Meningkatkan Keterampilan Smash Bola Voli Melalui Metode Tugas Siswa Kelas Viii Smp Negeri 1 Ketapan. Edukasi, Jurnal Pendidikan.

Kasih, I. (2018). Development Of Learning Model Smash Volleyball Based Circuit. International Journal Of Science And Research (Ijsr). Https://Doi.Org/10.31227/Osf.Io/Mz pga

Medeiros, A. I. A., Mesquita, I. M., Marcelino, R. O., \& Palao, J. M. (2014). Effects Of Technique, Age And Player's Role On Serve And Attack Efficacy In High Level Beach Volleyball Players. International Journal of Performance Analysis In Sport. Https://Doi.Org/10.1080/24748668. 2014.11868751

Miltner, O., \& Wurm, M. (2017). Volleyball. In Foot And Ankle Sports Orthopaedics. Https://Doi.Org/10.1007/978-3-31915735-1_70

Munawaroh, I. (2016). Urgensi Penelitian Dan Pengembangan. Universitas Negeri Yogyakarta.

Nurfalah, S., Hanif, A. S., \& Satyakarnawijaya, Y. (2019). Model Latihan Smash Dalam Permainan Bola Voli Untuk Pemula. Jurnal Pendidikan Olahraga. Https://Doi.Org/10.31571/Jpo.V8i1. 1216

Pranopik, M. R. (2017). Pengembangan Variasi Latihan Smash Bola Voli.
Jurnal

Prestasi. Https://Doi.Org/10.24114/Jp.V1i1.6 495

Rahadian, R. (2019). Model Pembelajaran Smash Bolavoli Pada Siswa Sekolah Menengah Kejuruan. Biormatika : Jurnal Ilmiah Fakultas Keguruan Dan Ilmu Pendidikan. Https://Doi.Org/10.35569/Biormatik a.V5i01.412

Rahman, A., Sahputra, R., \& Wakidi. (2014). Peningkatan Ketepatan Dan Kecepatan Smash Bola Voli Dengan Penerapan Media Audio Visual Pada Kelas Viii Smp Negeri 1 Pinoh Utara. Jurnal Pendidikan Jasmani Kesehatan Dan Rekreasi (Penjaskesrek).

Reeser, J. C., Fleisig, G. S., Bolt, B., \& Ruan, M. (2010). Upper Limb Biomechanics During The Volleyball Serve And Spike. Sports Health.

Https://Doi.Org/10.1177/194173811 0374624

Reeser, J. C., Fleisig, G. S., Bolt, B., \& Ruan, M. (2015). The Volleyball Serve And Spike. Sports Health.

Risma, S. A., Dlis, F., \& Samsudin, S. (2020). Variation Of Volleyball Basic Technique Through Games Approach. Active: Journal Of Physical Education, Sport, Health And Recreation. Https://Doi.Org/10.15294/Active.V9 i2.39056

Srianto, W. (2018). Pengembangan Model Latihan Teknik Smash Dalam Olahraga Bola Voli. Trihayu: Jurnal Pendidikan Ke-Sd-An. 